\title{
Nutrition of the southern sea garfish Hyporhamphus melanochir: gut passage rate and daily consumption of two food types and assimilation of seagrass components*
}

\author{
D. W. Klumpp ${ }^{1 * *}$ and P. D. Nichols ${ }^{2}$ \\ ${ }^{1}$ School of Botany and ${ }^{2}$ Department of Organic Chemistry, University of Melbourne, Parkville, Victoria 3052, Australia
}

\begin{abstract}
The southern sea garfish Hyporhamphus melanochir fed on the seagrass Heterozostera tasmanica for $13 \mathrm{~h}$ during daylight, ingesting an estimated 3 gut volumes of plant matter, equivalent to $500 \mathrm{~kJ} \mathrm{~d}^{-1} \mathrm{~kg}^{-1} \mathrm{dry}$ wt. No cellulase was detected in garfish digestive tissues, and gut $\mathrm{pH}$ was near neutral, but the pharyngeal mill efficiently triturated the seagrass tissue. Seagrass frond was assimilated at an efficiency of 38\% (organic matter), $28 \%$ (energy), $50 \%$ (protein) and $76 \%$ (lipids), these being equivalent to the total components available in seagrass cell contents. Nocturnally emergent crustaceans were preyed upon by garfish over a period of $6 \mathrm{~h}$ and were processed at half the rate of seagrass. The daily energy intake, and probably assimilation, from this source was $223 \mathrm{~kJ} \mathrm{~kg}^{-1} \mathrm{dry}$ wt. Although the crustaceans consumed were only a third the quantity of seagrass, it was reasoned to be an essential source of protein, and at least as important as seagrass in satisfying the energy requirements of $H$. melanochir.
\end{abstract}

\section{INTRODUCTION}

Living seagrass fronds are considered to be of low nutritional quality in terms of digestibility and nitrogen-to-carbon ratio, when compared with algae or animal foods (Phillips and McRoy, 1980). Certainly only a minor proportion of seagrass production is grazed (Fenchel, 1972; Harrison and Mann, 1975; Ott and Maurer, 1977). Nevertheless, seagrass is a major part of the diet of a variety of animals, including fishes (Randall, 1967; Ogden, 1976), and little is known about the mechanisms of digestion or efficiency of utilization of ingested seagrass in these cases.

Garfish or halfbeaks, of the family Hemirhamphidae, have generally been described as herbivores, feeding mainly on the fronds of zosteracean seagrass (Thompson, 1957, 1959; Talwar, 1962; Collette, 1974). A more complex feeding pattern has emerged for the southern

\footnotetext{
- Part $\Gamma$ in the series 'Study of Food Chains in Seagrass Communities

- Present address: Biologische Anstalt Helgoland, Notkestraße 31, D-2000 Hamburg 52
}

sea garfish Hyporhamphus melanochir (Valenciennes) which 'switches' from seagrass fronds during daylight to emergent benthic crustaceans, mainly amphipods, at night (Robertson and Klumpp, 1983). These authors propose that $H$. melanochir feeds preferentially on small crustaceans when these are available in the water column. The digestive system in hemirhamphids consists of a straight tubular alimentary canal without stomach or appendages (Suyehiro, 1942) and the ratio of gut-to-body length is only 0.5 (Robertson and Klumpp, 1983) which is atypical of a herbivore. Seagrass ingested by $H$. melanochir is thoroughly macerated (Robertson and Klumpp, 1983), presumably by the action of pharyngeal teeth that are present in all hemirhamphids.

The present study examines aspects of nutrition in Hyporhamphus melanochir, with particular emphasis on the digestion of seagrass and subsequent assimilation of its nutrient components. Measurement of the passage rate for animal and plant material down the gut is used to estimate the ingestion rates for each of these food types. We discuss the relative importance of seagrass and animal food to the nutrition of this fish. 


\section{MATERIALS AND METHODS}

\section{Collection of samples}

Hyporhamphus melanochir tissues and gut contents were obtained from the field at Duck Point in Corner Inlet (S.E. Australia) with methods previously described in a study of the diel feeding habits of this fish (see Robertson and Klumpp, 1983). The diel feeding study in Corner Inlet was made in mid November when water temperature averaged $17^{\circ} \mathrm{C}$. Although garfish are commonly reported as feeding on Zostera, it was established that $H$. melanochir in Corner Inlet consumes Heterozostera tasmanica.

Robertson and Klumpp (1983) have recorded the distinct and separate nature of ingested seagrass and animal material in the gut of Hyporhamphus meIanochir at $3 \mathrm{~h}$ intervals of the diel feeding cycle. In the present study the rates of movement of these 'food zones' along the simple tubular gut are examined as a convenient measure of gut passage time under natural conditions. Ten fish were examined at each time interval. The number of gut volumes of food consumed per day for both food types is then calculated, and with the known mass of food in the gut, used to estimate the weight of seagrass and crustaceans ingested in a day.

\section{Cellulase enzyme and gut $\mathrm{pH}$ analysis}

Liver, spleen and alimentary tract tissues and gut contents from garfish freshly caught during the seagrass feeding phase were analyzed for cellulase enzyme activity. These tissues were maintained and the extractions made at 0 to $4^{\circ} \mathrm{C}$. The extraction procedure is summarized below:

$1 \mathrm{~g}$ tissue $+10 \mathrm{ml} 0.05 \mathrm{M}$ acetate buffer ( $\mathrm{pH}$ 5.6)

$$
\downarrow
$$

Extract homogenized and filtered through Miracloth to remove fats and coarse material

$\downarrow$

Filtrate centrifuged at $10000 \mathrm{rpm}$ for $10 \mathrm{~min}$ $\downarrow$ Decanted supernatant $+85 \%$ ammonium sulphate to precipitate proteins

$\downarrow$

Centrifuge at $10000 \mathrm{rpm}$ for $10 \mathrm{~min}$

$\downarrow$

Suspend pellet in saturated ammonium sulphate

$$
\downarrow
$$

Centrifuge and discard liquid

$\downarrow$

Dissolve pellet in $10 \mathrm{ml}$ acetate buffer
$2.5 \mathrm{ml}$ aliquot desalted on a Sephadex G25 disposable gel filtration column (PD-10)

$\downarrow$

$3.5 \mathrm{ml}$ eluant

$\downarrow$

$+2 \mathrm{ml}$ substrate (carboxy methyl cellulose $1 \%$ solution)<smiles>[AlH]</smiles>

Incubation at $37^{\circ} \mathrm{C}$ water bath for $3 \mathrm{~h}$

$\downarrow$

Analysis of reducing sugar byproducts by SomogyiNelson method and detection on a spectrophotometer at $520 \mathrm{~nm}$.

The above procedure was repeated as the control without the addition of substrate, or with the enzymes deactivated by heat $\left(100^{\circ} \mathrm{C}\right)$ immediately following the addition of substrate. The procedure was checked by substituting active commercial cellulase enzyrne for the tissue extract.

Fluid from the gut contents of fore-, mid- and hindgut regions of freshly caught garfish was obtained by centrifugation and $\mathrm{pH}$ measured using a glass electrode.

\section{Nutrients in food and assimilation efficiency}

The guts of 40 garfish, caught near the peak of the seagrass-feeding phase, were grouped in tens and the contents removed in 3 equal linear segments of fore-, mid-and hind-gut regions. Part of the fresh material was analyzed for total lipids by the method in Nichols et al. (1982). The remainder was air dried, ground in a Wiley Mill and divided into (a) that for direct determination of neutral detergent fibre (NDF), acid detergent (ADF) and lignin by the methods of Van Soest and Wine $(1967)$; (b) that for oven drying $\left(80^{\circ} \mathrm{C}\right)$, and subsequent analysis for components: organic matter, energy and total nitrogen. Organic matter was determined by ashing in a muffle furnace $1550^{\circ} \mathrm{C}$, overnight), energy with a Gallenkamp ballistic bomb calorimeter (CB-370) and total nitrogen by autoanalyser and the standard micro-Kjeldahl technique. The commonly used multiple of 6.25 for converting total nitrogen to protein is probably valid for animal tissues, but Harrison and Mann (1975) have shown that only $37.5 \%$ of nitrogen in young Zostera fronds is associated with protein. Heterozostera tasmanica protein levels are therefore calculated from nitrogen data according to the formula:

$$
\% \text { protein }=\% \text { total nitrogen } \times 6.25 \times 0.375
$$

Tips of fronds $(5 \mathrm{~cm})$ from epiphyte-free Heterozostera tasmanica were collected concurrently with garfish gut 
contents and analysed for nutrient components as described above. The proportion of components in the 'juice' of seagrass fronds was determined as follows:

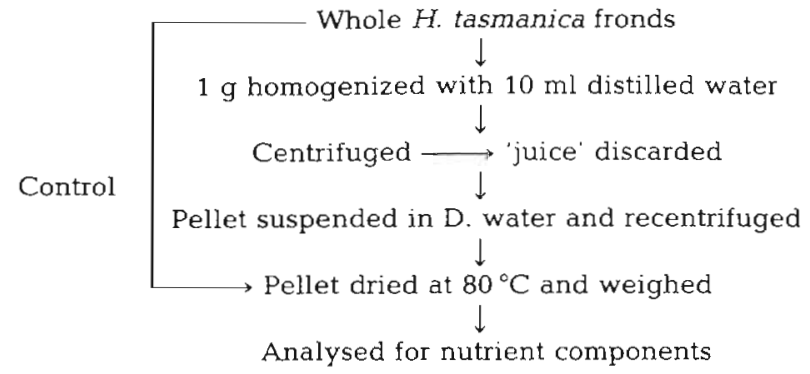

The amount of components in seagrass 'juice' is then the difference in component content of control and extracted fronds. The proportion of organic matter in cell contents relative to plant mass can also be determined as the difference between percentage organic matter and ash-free NDF.

Several terms are used in fish nutrition studies to describe a single process and these are often ambiguous. An example is the use of assimilated, digested and absorbed nutrients to describe the difference between components in food and faeces. 'Digestibility' has been objected to by Pandian (1967) because digested foods are not necessarily assimilated or absorbed. The "apparent digestibility coefficient' of Crampton and Harris (1969), is here referred to as assimilation efficiency (AE) and calculated as follows:

$\% \mathrm{AE}=100-$

$\left[\frac{\% \text { lignin in tood }}{\% \text { lignin in gut content }} \times \frac{\% \text { component in gut content }}{\% \text { component in food }}\right] \times 100$

Typically in this formula the components of food and faeces are compared. In the present study it was not possible to collect true faeces from the field or in the laboratory, therefore component utilization is examined in progressive segments of the gut, previously referred to as fore-, mid-, and hindgut. Lignin provides a natural marker to correct for the contribution of components from sloughed linings of the gut wall and the fishes' digestive secretions. It is assumed that hindgut material is representative of faeces and that lignin is not digested.

\section{RESULTS}

\section{Gut passage time and daily food consumption}

Seagrass, crustacean food, and empty regions formed distinct separate bands along the gut of Hyporhamphus melanochir (Fig. 1). The mean ( $\mathrm{n}=10)$ relative position of these bands were compared at successive $3 \mathrm{~h}$ intervals over $24 \mathrm{~h}$ in order to calculate

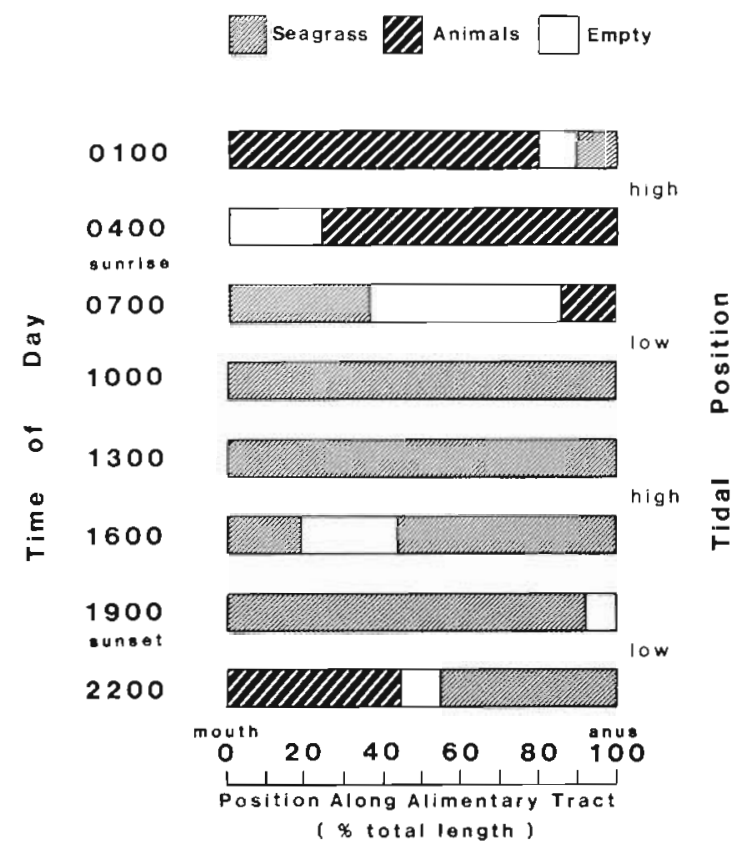

Fig. 1. Hyporhamphus melanochir. Mean ( $=10)$ position of food items (seagrass and crustaceans) and empty regions, along the alimentary tract at $3 \mathrm{~h}$ intervals of the diel feeding cycle

the rate of movement of these 2 food types. The most accurate measure of gut passage time was obtained over intervals when it was possible to measure the exact distance a 'food front' had travelled, e.g. for crustacean material between $22.00 \mathrm{~h}$ and $01.00 \mathrm{~h}$ and for seagrass material between $16.00 \mathrm{~h}$ and $19.00 \mathrm{~h}$. Crustacean material occupied $45 \pm 7 \%$ of the gut at $22.00 \mathrm{~h}$ and $80 \pm 14 \%$ by $01.00 \mathrm{~h}$ which is a gut passage rate of $11.6 \% \mathrm{~h}^{-1}$. At $16.00 \mathrm{~h}$ seagrass material formed 2 bands separated by an empty space. The anterior band was $14 \pm 3 \%$ of the gut length at $19.00 \mathrm{~h}$ and $3 \mathrm{~h}$ later filled $92 \pm 12 \%$ of the gut, i.e. a rate of $26 \% \mathrm{~h}^{-1}$. Where a 'food front' was recognizable at one period only, the passage rate was calculated as the length of that food band divided by the maximum time interval of $3 \mathrm{~h}$ and is therefore a minimum rate. For example, between $07.00 \mathrm{~h}$ and $10.00 \mathrm{~h}$ ingested seagrass moved from $37 \pm 17 \%$ to $100 \%$ of the total gut length which is a rate of $21 \% \mathrm{~h}^{-1}$. Over the sampling intervals $04.00 \mathrm{~h}$ to $07.00 \mathrm{~h}$ and $19.00 \mathrm{~h}$ to $22.00 \mathrm{~h}$ a maximum passage rate is calculated by assuming that the feeding interval commenced at sunrise $(06.00 \mathrm{~h})$ and sunset $(20.00 \mathrm{~h})$, respectively. Thus in these cases the calculated gut passage rates are $37 \% \mathrm{~h}^{-1}$ for seagrass (37 $\pm 7 \%$ of gut filled in $1 \mathrm{~h}$ ) and $27 \% \mathrm{~h}^{-1}$ for crustaceans ( $45 \pm 7 \%$ of gut filled in $2 \mathrm{~h}$ ).

The above data are used to construct a feeding model (Fig. 2). Feeding was assumed to be continuous 


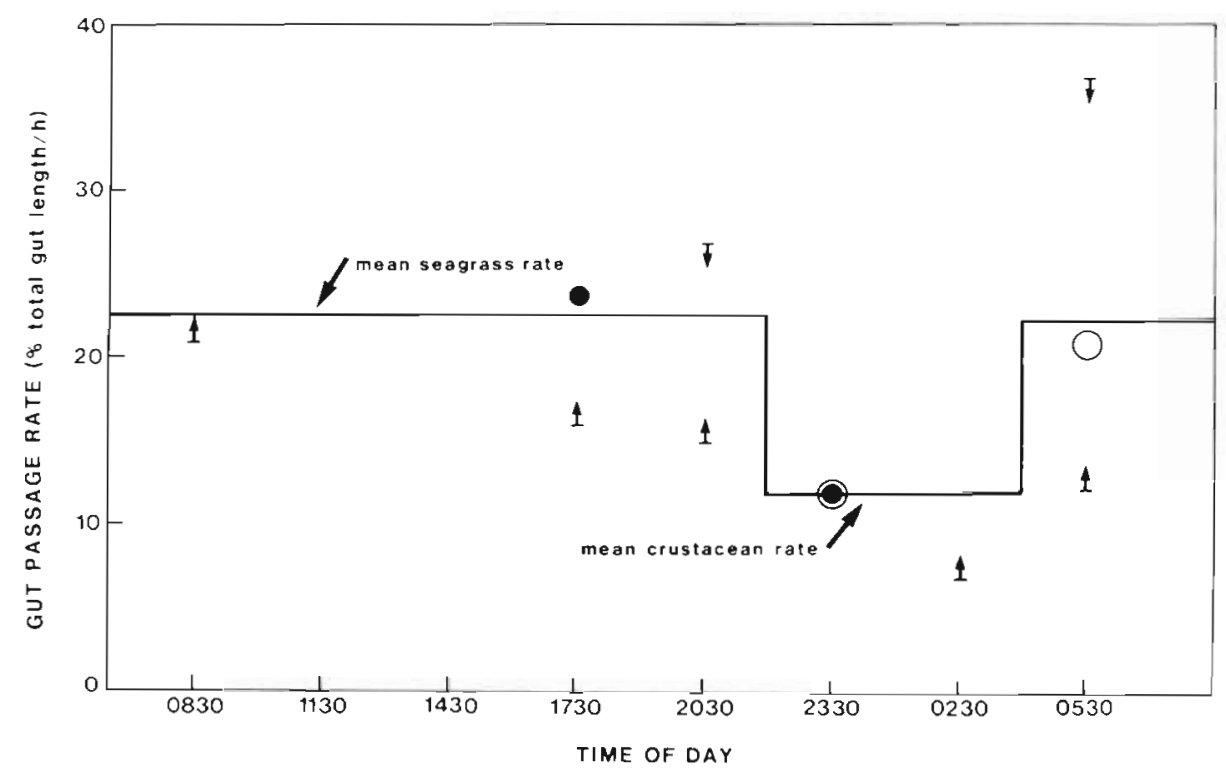

Fig. 2. Hyporhamphus melanochir. Rate of food passage (seagrass and crustaceans) along the gut at $3 \mathrm{~h}$ intervals of the diel feeding cycle. Gut passage rate shown as closed (seagrass) and open (crustaceans) circles when the exact distance of food passage could be calculated for a $3 \mathrm{~h}$ interval, and as arrows depicting maximum $I$ and $\uparrow$ minimum rates when the distance of food passage was related to an estimated time interval

with food passing along the gut in a 'conveyor-belt' manner. The process operated at mean speeds of $22.5 \%$ gut length $\mathrm{h}^{-1}$ and $12 \%$ gut length $\mathrm{h}^{-1}$ during periods of seagrass and crustacean ingestion, respectively. Seagrass feeding was observed to commence between $04.00 \mathrm{~h}$ and $07.00 \mathrm{~h}$ (i.e. near sunrise). By $22.00 \mathrm{~h}$ the garfish had commenced feeding on crustaceans while seagrass had moved along $55 \pm 7 \%$ of the gut length at the rate of $22.5 \% \mathrm{~h}^{-1}$. The 'switch-over' in feeding is therefore calculated to occur around $19.30 \mathrm{~h}$, i.e.

$$
22.00 \mathrm{~h}-\frac{55 \%}{22.5 \% \mathrm{~h}^{-1}}
$$

There was a break in seagrass feeding between $13.00 \mathrm{~h}$ and $16.00 \mathrm{~h}$ observed as an empty space $25 \pm 6 \%$ of the gut length and corresponding to a time interval of $1 \mathrm{~h}$, i.e.

$$
\frac{25 \%}{22.5 \% \mathrm{~h}^{-1}}
$$

Thus garfish fed upon seagrass for a total of $13 \mathrm{~h}$ at a gut passage rate of $22.5 \% \mathrm{~h}^{-1}$; this is equivalent to 3 gut volumes of food $\mathrm{d}^{-1}$.

Ingested crustaceans occupied $45 \pm 7 \%$ of the gut by $22.00 \mathrm{~h}$, and for the purpose of the model, commencement of feeding on crustaceans is calculated to be 20.00 h, i.e.

$$
22.00 \mathrm{~h}-\frac{45 \%}{22.5 \% \mathrm{~h}^{-1}}
$$

This is consistent with an observed cessation in feeding between the 'switch' from seagrass to crustaceans. Crustaceans were preyed upon between $20.00 \mathrm{~h}$ and $22.00 \mathrm{~h}$ at a passage rate of $22.5 \% \mathrm{~h}^{-1}$ and subsequently at the rate of $12 \% \mathrm{~h}^{-1}$. By $04.00 \mathrm{~h}$ feeding on crustaceans had ceased and the gut was $25 \%$ empty in the foregut region. Crustaceans were therefore consumed until $02.00 \mathrm{~h}$, i.e.

$$
04.00 \mathrm{~h}-\frac{25 \%}{12 \% \mathrm{~h}^{-1}}
$$

Feeding for $2 \mathrm{~h}$ at $22.5 \% \mathrm{~h}^{-1}$ and $4 \mathrm{~h}$ at $12 \% \mathrm{~h}^{-1}$ is equivalent to a combined consumption of 1 gut volume of crustacean material per day. The crustacean feeding period of $6 \mathrm{~h}$ was followed by another non-feeding period of $3.5 \mathrm{~h}$, preceding the 'switch-over' to seagrass food.

The gut of Hyporhamphus melanochir was 90 to $100 \%$ full by volume at all sampling periods except at $04.00 \mathrm{~h}, 07.00 \mathrm{~h}$ and $16.00 \mathrm{~h}$ when fullness decreased to between 50 and $75 \%$ (Fig. 1). An analysis of variance (Newman-Keuls multiple range test) showed that the total weight of food in the gut (Fig. 3) at 04.00, 07.00 and $16.00 \mathrm{~h}$ was significantly lower than at other times $\left(F_{[0.05], 7,72}=6.55\right)$. Dry weight (mg) of either food type in full guts was not significantly different, and was linearly correlated $(r=0.95)$ with dry weight of fish (g) according to the regression $y=1.1+12.5 \mathrm{wt}$. The fish examined ranged in size from 12 to $40 \mathrm{~cm}$ length to caudal fork (LCF) and 1.2 to 52.0 dry wt., with a mean weight of $3.4 \mathrm{~g}$. Thus the average fish had $40 \mathrm{mg}$ food in a full gut. The daily consumption of food was therefore $120 \mathrm{mg}$ ( 3 gut volumes) of seagrass and $40 \mathrm{mg}$ of crustaceans.

\section{Digestion of seagrass}

Green seagrass tissue in the foregut had been thoroughly macerated by the pharyngeal plates. The ingested seagrass consisted mostly of $5 \mathrm{~cm}$ lengths of 
Table 1. Nutrient components in the entire fronds and extractable 'juice' of seagrass Heterozostera tasmanica plus the assimilation of these nutrients by the southern sea garfish Hyporhamphus melanochir

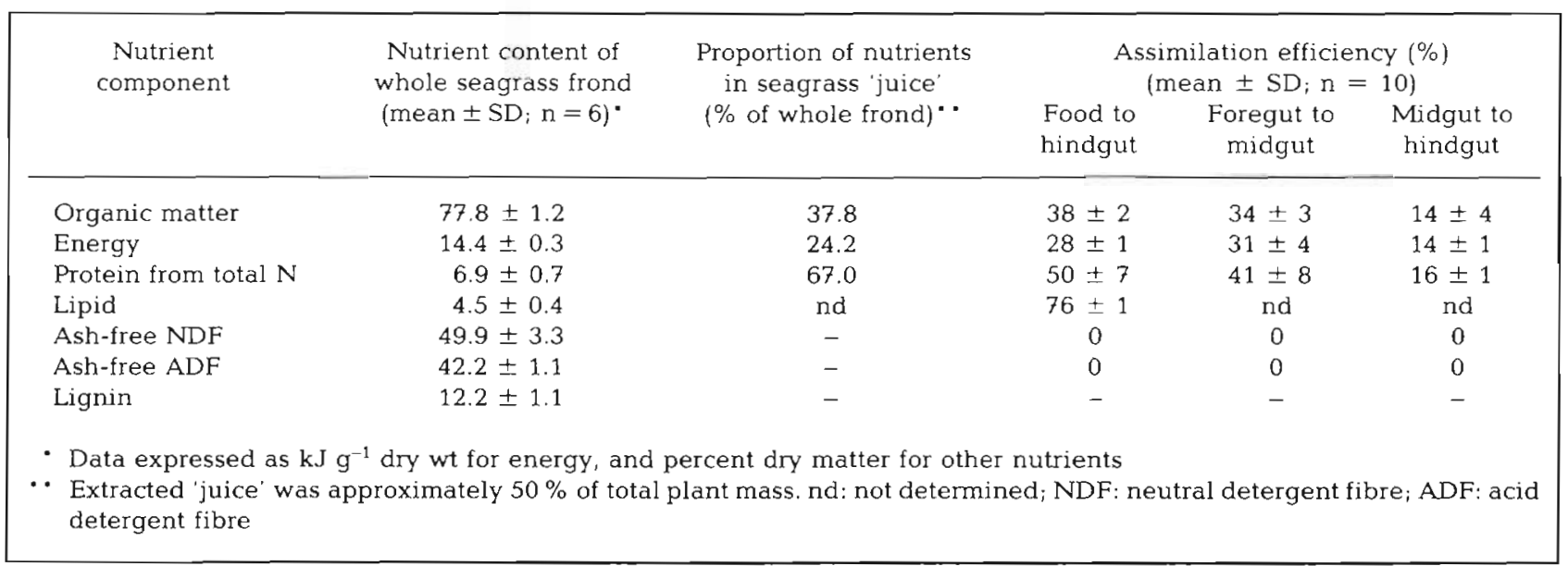

tangled fronds in which a high proportion of cells had been ruptured. The food material in different segments of gut was similar in general appearance and retained green pigmentation. The foregut material was usually mixed with mucous secretions while the hindgut material appeared drier and fibrous. The $\mathrm{pH}$ varied from 6.5 to 6.7 in the foregut, 6.9 in midgut, and 6.6 to 7.0 in the hindgut. Analysis for cellulase enzyme activity was negative for all tissues tested.

\section{Assimilation of nutrients from seagrass}

Young fronds of Heterozostera tasmanica, the main plant food of garfish in Corner Inlet, comprised $78 \%$ organic matter of which $38 \%$ was contained in the extractable 'juice' (Tab. 1). The 'juice', which is possibly the most relevant food of the garfish, contributes
$24 \%$ to the total energy of $14.4 \mathrm{~kJ} \mathrm{~g}^{-1}$ in seagrass fronds. The majority of protein $(67 \%$ of $6.9 \%)$ was found in the 'juice' portion of seagrass fronds. The garfish assimilated $38 \%$ of organic matter, $28 \%$ of energy and $50 \%$ of protein from whole seagrass fronds, indicating that the 'juice' components were apparently assimilated with $100 \%$ efficiency. Lipid content was $4.5 \%$ in whole fronds, and although there are no comparative data on lipids in 'juice', there was a high assimilation ( $76 \%$ efficiency) of lipids from seagrass. The total fibre content (NDF) of $H$. tasmanica was $50 \%$, of which hemicellulose (NDF-ADF) was $7.7 \%$ and cellulose (ADF-lignin) was $30 \%$. No assimilation of seagrass fibre by garfish was detected. The absorption of nutrients along the gut shows that most assimilation $(70 \%)$ occurs between the fore- and midgut regions.
Fig. 3. Hyporhamphus melanochir. Mass of food in the gut in relation to body weight, i.e. feeding intensity, at $3 \mathrm{~h}$ intervals of the diel feeding cycle. Data presented as amounts of seagrass (open circles) and crustaceans (stars) and the total mass (mean $\pm \mathrm{SD}$ ) of both food types (closed circles) in the gut; sunrise and sunset indicated by end and beginning respectively of a thickened $x$-axis; high (HT) and low (LT) tide also shown

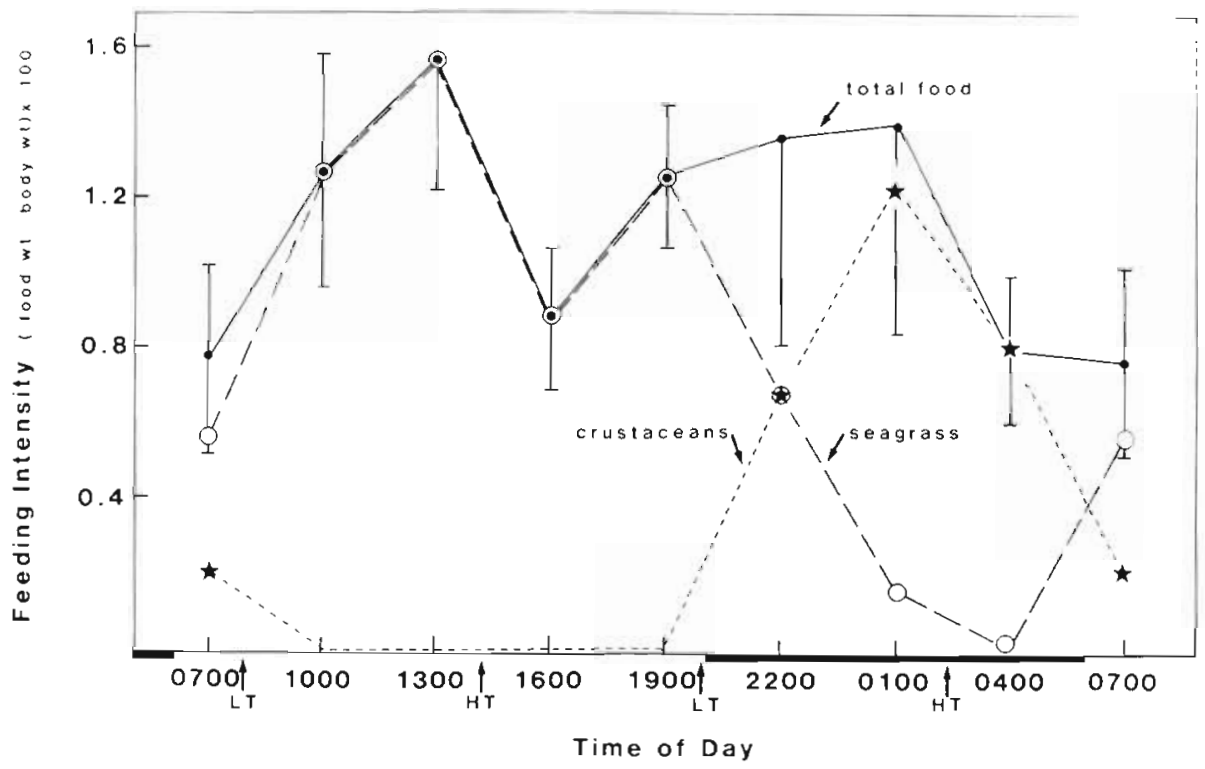




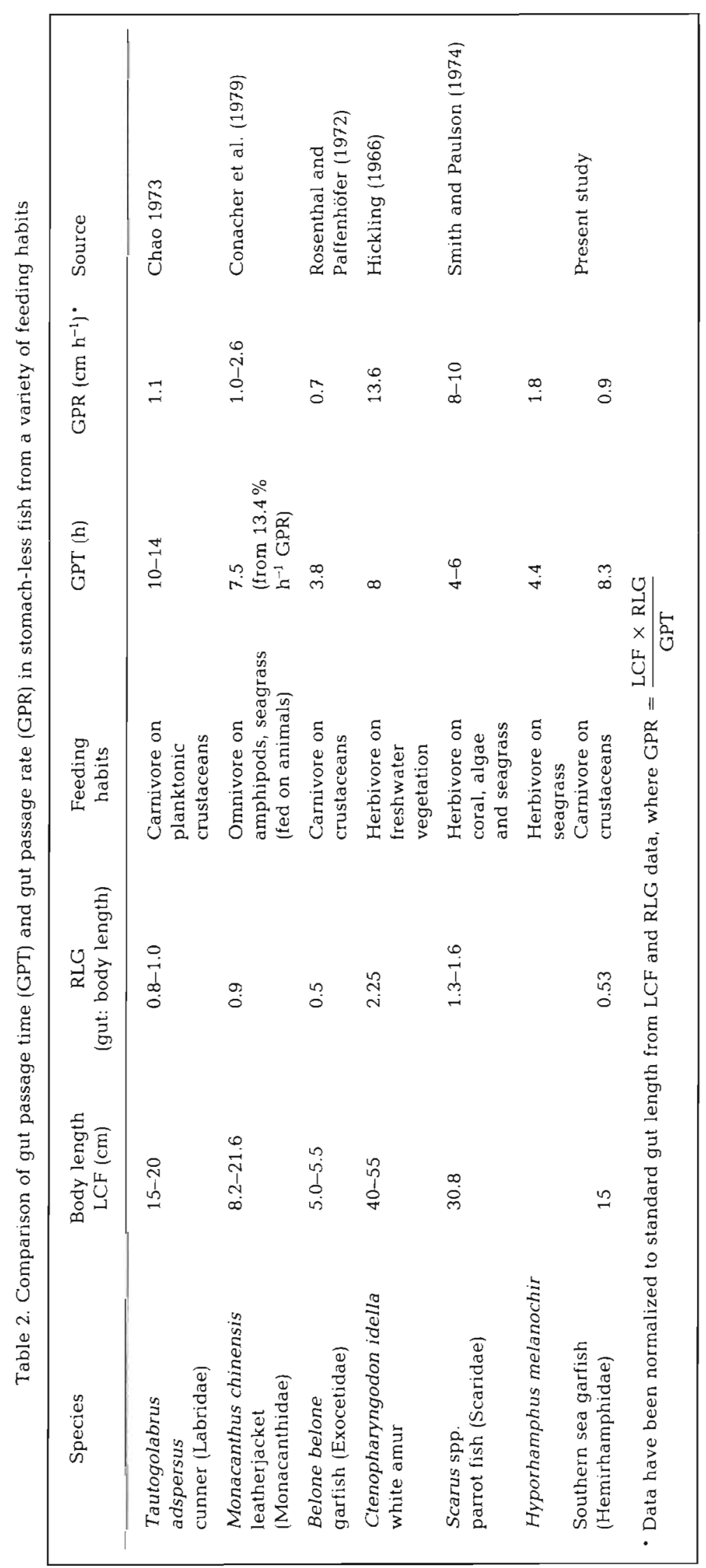




\section{DISCUSSION}

The main limitation to the utilization of plant food by fish is the penetration of plant cell walls, since fish possess the necessary complement of enzymes (Beauvalet, 1933; Ishida, 1936; Fish, 1960; Hickling, 1966; Moriarty, 1973; Payne, 1978) for the digestion and assimilation of nutritious cell contents. A further deterent to herbivory in fishes, for which little information is available, is the presence of toxic substances in plants (Ogden and Lobel, 1978; Nicotri, 1980). Fish do not possess an enzymatic mechanism for the digestion of plant cell walls, e.g. cellulase (review by Kapoor et al., 1975); however, alternative mechanisms are found in fish. These are (1) the lysis of cells in an acidic ( $\mathrm{pH} 2$ to 4) stomach medium (Fish, 1960; Moriarty, 1973; Bowden, 1976; Lobel, 1981); (2) mechanical action of the mouthparts or the gizzard (Al-Hussaini, 1947; Hicking, 1966; Lobel, 1981). The stomachless fishes, with representatives in 15 families including the Hemirhamphidae, typically possess a pharyngeal mill (Chao, 1973) and a gut pH of $7.0 \pm 2.0$ (Ishida, 1936; Barrington, 1957; Gohar and Latif, 1961). An acidic gut would be superfluous, and indeed impede the action of enzymes such as amylase, invertase, lipases and the tripsin-like proteases which show optimum activity around neutral pH (Fish, 1960; Karlson, 1968). The above enzymes have been recorded in stomachless fish (Chesley, 1934; Fish, 1960; Hickling, 1966; Moriarty, 1973) and are likely to be important in the digestion of seagrass in the gut of Hyporhamphus melanochir $(\mathrm{pH}$ 6.5 to 7.0 ).

The current methods for estimating food consumption in fish are mostly derived from studies on fish that possess a defined stomach and consume discrete meals, which are then evacuated at exponential rates (Elliot, 1972; Thorpe, 1977; Elliot and Persson, 1978). The limited data available on the feeding of Hyporhamphus melanochir do not justify a more complicated model of food consumption than that proposed (Fig. 2), and this is essentially that of Bajkov (1935). The garfish has a simple straight tubular gut (Suyehiro, 1942) and feeds almost continuously, with food passage rate being nearly constant for the ingestion of a particular food type. The main limitation of this proposed model is the uncertainty of gut passage rate, or even that ingestion is actually taking place, when no comparison of food markers was possible. This was a particular problem during the daylight feeding on seagrass, e.g. $10.00 \mathrm{~h}$ to $13.00 \mathrm{~h}$ (Fig. 1), where it was assumed that food was being ingested at the mean calculated rate. This assumption seems safe since the gut remained full in terms of food volume and weight during these periods (Fig. 1 and 3).

The ratio of gut length to body length (RLG) in fish is frequently used as a general guide to feeding habits (Suyehiro, 1942; Al-Hussaini, 1947; Hickling, 1966; Kapoor et al., 1975; Van Dyke and Sutton, 1977) being generally less than 0.1 for camivores, greater than 3.0 for herbivores and intermediate in omnivores. The same trend is evident in our summary of comparative data on stomachless fish in Table 2 although the garfish would be incorrectly defined as a carnivore. Gut passage rate (GPR) is perhaps a more sensitive indicator than RLG for feeding in omnivores, e.g. garfish, and is considerably faster for plant than for animal food. In fish, GPR is found to vary with both food quantity (Tyler, 1970; Elliot, 1972; Flowerdew and Grove, 1979; Tseitlin, 1980) and quality (Rozin and Mayer, 1964; Lee and Putnam, 1973; Grove et al., 1978) and usually shows an increase with an increase in ration size. For example, a continuous supply of different food types to carnivorous garfish Belone belone (Exocetidae) resulted in a GPR for zooplankton that was 57 to $64 \%$ slower than for Tubifex (Rosenthal and Paffenhöfer, 1972). It is not certain whether food quality or quantity were responsible for these observed differences since the capture rate, and hence ingestion, of Tubifex is expected to be higher than for mobile zooplankton. The gut passage time (GPT) averaged $3.8 \mathrm{~h}$ for $B$. belone ( 5 to $5.5 \mathrm{~cm}$ ) consuming crustaceans (Rosenthal and Paffenhöfer, 1972) which is equivalent

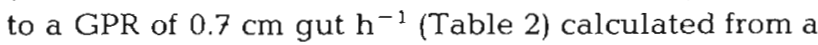
gut: LCF ratio of 0.5 (Al-Hussaini, 1947). This compares favourably with a GPT of $8.3 \mathrm{~h}$, or GPR of $0.9 \mathrm{~cm}$ gut $\mathrm{h}^{-1}$, for the closely related $H$. melanochir $(15 \mathrm{~cm}$ LCF) consuming crustaceans (Tab. 2). The GPT for $H$. melanochir consuming seagrass was $4.4 \mathrm{~h}$ or $2 \mathrm{~cm}$ gut $\mathrm{h}^{-1}$ GPR, i.e., twice the rate of crustaceans. These differences in GPT are probably a function of ingestion rate. Seagrass is available to Hyporhamphus melanochir as an unlimited, static food resource, whereas the dominant crustacean prey are expected to be evasive, less abundant, and vulnerable to predation during a limited period when they emerge into the water column above the seagrass beds at night (Robertson and Howard, 1978; Robertson and Klumpp, 1983; Fig. 1 and 3). A difference in nutritive qualities of seagrass and crustacean food may also contribute to the observed differences in GPR. The dilution of food quality with inorganic material has been shown to increase ingestion and egestion rates in fish, i.e. to result in less time to empty the gut (Rozin and Mayer, 1964; Lee and Putnam, 1973). The presence of other non-digestible materials, such as seagrass fibre, may be expected to have a similar effect on GPR in $H$. melanochir. It was calculated that a garfish of $3.4 \mathrm{~g}$ dry weight ingests $120 \mathrm{mg}$ (i.e. $3.5 \%$ of body weight) of seagrass $\mathrm{d}^{-1}$. This is equivalent to $1.7 \mathrm{~kJ}$ energy of which $0.5 \mathrm{~kJ}$ (or $147 \mathrm{~kJ}$ $\mathrm{kg}^{-1}$ dry weight) was assimilated. Crustacean food 
was ingested at the rate of $40 \mathrm{mg} \mathrm{d}^{-1}$ (i.e. $1 \%$ of body weight) and assimilated at an assumed efficiency of 85 to $98 \%$. Using the data on energy content of amphipods from Conacher et al. (1979) we can predict that the daily crustacean diet of garfish provides 0.64 to $0.74 \mathrm{~kJ}$ of assimilated energy. The assimilated energy from both food types is then approximately $1.2 \mathrm{~kJ} \mathrm{~d}^{-1}$ or $353 \mathrm{~kJ} \mathrm{~kg}^{-1} \mathrm{dry}$ wt $\mathrm{d}^{-1}$, nearly $60 \%$ of which is derived from the crustaceans. The fanbellied leatherjacket Monacanthus chinensis - one of the important consumers of seagrass and micro-crustaceans in Australian seagrass beds - has been estimated to consume daily $152 \mathrm{~kJ}$ energy $\mathrm{kg}^{-1}$ wet weight (Conacher et al., 1979). The garfish by comparison consumes $180 \mathrm{~kJ}$ energy on a wet weight basis (dry: wet ratio $=0.25$ ). The difference is expected because garfish are highly active, fast swimming fish, which feed almost continuously, compared with leatherjackets, which are cryptic inhabitants of the seagrass canopy being active during only part of the day.

Growth is a component of the energy balance of garfish for which data are available. Growth rates in Hyporhamphus melanochir from South Australia have been determined by Ling (1958) from field data on age and length frequency distribution. Our data agreed closely with Ling's calculated length to weight relationship (log wt $=3 \log \mathrm{L}-5.6$ ) and was used to estimate successive annual growth rates over the first 5 yr, for which data are available. Fish of year Class I, II, III, IV and $V$ had lengths of 9.5, 16.5, 22.5, 27.2 and $32.6 \mathrm{~cm}$. The growth rates are 4.1, 19.0, 37.3, 74.0 and $128 \mathrm{~g}$ wet $\mathrm{wt} \mathrm{yr}^{-1}$, corresponding to an energy content of $16,76,149,296$ and $512 \mathrm{~kJ}$, calculated from a garfish mean energy content of $4.1 \mathrm{~kJ} \mathrm{~g}^{-1}$ wet wt (unpubl. own data). The average-sized fish of the present study $(15.5 \mathrm{~cm}$, year Class II) therefore has required $76 \mathrm{~kJ}$ energy for its preceding year of growth. We estimate the intake of such a fish to be, at maximum, $909 \mathrm{~kJ} \mathrm{yr}^{-1}$ of which $445 \mathrm{~kJ} \mathrm{yr}^{-1}$ is assimilated. This represents a gross growth efficiency of $8 \%$ and a net growth efficiency of $17 \%$ which is within the range reported for fish under natural conditions (Mann, 1965; Conover, 1978). Assuming that our estimates of energy consumption and assimilation are accurate, the garfish has a surplus of $369 \mathrm{~kJ}$ energy, i.e., $83 \%$ of assimilated energy, available for metabolism during the second year of growth.

Data are not available on the metabolic energy requirements of garfish or related species. The regression of basal metabolic energy requirement to fish weight at $20^{\circ} \mathrm{C}, \mathrm{R}=35.8$ Weight $^{0.81}$, as proposed by Winberg (1956), and derived mainly from fresh water fish studies, can be used as a guide to the energy requirement of garfish. The respiratory rate value in the above regression was adjusted for a water tempera- ture of $17^{\circ} \mathrm{C}$ using the table of Winberg (1956) as quoted in Grodzinski et al. (1975, p. 127). Under these conditions a garfish of average weight (13.6 g wet) is calculated to require $222 \mathrm{cal}$ or $0.9 \mathrm{~kJ}$ energy $\mathrm{d}^{-1}$ for basal metabolism, and twice this amount if active (Winberg, 1956; Mann, 1969). Such a demand exceeds our measured estimate of assimilated energy by $50 \%$. Mann (1965) discusses the limitations of the Winberg formula and points out that, whereas the regression coefficient varies little from 0.8 , the respiratory rate value can range widely between species from the theoretical $35.8 \mathrm{cal} \mathrm{g}^{-1}$. wet weight $\mathrm{d}^{-1}$.

The nutrient content of seagrass is considered to be low in comparison with other vascular plants (Birch, 1975). However, Lobel and Ogden (1981) noted that seagrasses had the highest nutrient quality in terms of energy and protein content when compared with algae of a coral reef lagoon. Similarly a study of herbivore food preference by Nicotri (1980), in which Zostera and 17 different algae are compared, found that Zostera ranked 3rd in terms of organic matter and energy but only 13 th in terms of nitrogen. Energy levels in seagrasses range from 12 to $18 \mathrm{~kJ} \mathrm{~g}^{-1}$ dry wt (McRoy, 1970; Birch, 1975; Conacher et al., 1979) with $14.4 \mathrm{~kJ}$ $\mathrm{g}^{-1}$ in Heterozostera tasmanica of the present study. A $C: N$ ratio of less than $17: 1$ is considered necessary in animal nutrition (Russell-Hunter, 1970), but seagrasses and most macrophytic algae exceed this (Mann, 1972; Harrison and Mann, 1975). Seagrasses are reported to have a nitrogen content of between 0.7 and $4.8 \%$ (Vinogradov, 1953; Burkholder et al., 1959; Birch, 1975; Harrison and Mann, 1975; Murray et al., 1977), with $2.9 \%$ recorded in the present study. It has already been noted that only a third of this nitrogen is associated with protein in Zostera (Harrison and Mann, 1975)

The consumption of crustaceans by Hyporhamphus melanochir must be important in maintaining a balanced intake of nitrogen since the protein content of zooplankton is relatively high (40 to $80 \%$; Mayzaud and Martin, 1975) and the published estimates for nitrogen assimilation efficiency in carnivorous fish are around $90 \%$ (Buckley and Dilmann, 1982) compared with $50 \%$ assimilation of seagrass nitrogen by $H$. melanochir. Also the crustacean food of $H$. melanochir is energy-rich (19 $\mathrm{kJ} \mathrm{g}^{-1}$ in amphipods from an Australian seagrass bed; Conacher et al., 1979) compared with seagrass of which only $3 \mathrm{~kJ} \mathrm{~g}^{-1}$ is actually available as cell contents (Table 1). Seagrass energy was assimilated at $28 \%$ efficiency in $H$. melanochir and this is at the lower end of the range (20 to $60 \%$ ) reported for herbivorous fish (Mathaven et al., 1976; Van Dyke and Sutton, 1977; Conacher et al., 1979; Lobel and Ogden, 1981). Assimilation of energy in carnivorous fish is estimated to be 85 to $98 \%$ (Beamish 
et al., 1975). Thus, on a weight for weight basis, the crustacean diet of $H$. melanochir will provide a richer source of available energy and protein than seagrass.

The southern Australian garfish seems adapted for utilizing rich food resources of a seagrass bed. The feeding strategy of this fish is based on the grazing of seagrass, a vast resource of relatively low nutritional quality. Ingested seagrass is passed through the gut in the relatively short time necessary to fully extract nutrient components, such as simple sugars, from the cell contents. The small crustaceans that swarm above the seagrass canopy at night form a limited but highly nutritious resource exploited by the garfish. In turn, the faeces produced by abundant garfish feeding on seagrass are probably of major importance to the detrital food web and in the recycling of nutrients within the seagrass bed.

Acknowledgements. This study was funded through a Melbourne University Research Fellowship to D. Klumpp. We are grateful to Dr. P. M. Attiwill for his kind support and provision of facilities and to Mr. C. Walsh for assistance in the field. We thank Professor J. G. Field and Drs. C. Griffiths and K. Koop for their helpful criticism of the manuscript.

\section{LITERATURE CITED}

Al-Hussaini, A. H. (1947). The feeding habits and the morphology of the alimentary tract of some teleosts. Publs mar. biol. Stn Ghardaqa 5: 1-61

Bajkov, A. D. (1935). How to estimate the daily food consumption of fish under natural conditions. Trans. Am. Fish. Soc. 65: 288-289

Barrington, E. J. (1957). The alimentary canal and digestion. In: Brown, M. (ed.) The physiology of fishes. Academic Press, New York, p. 109-161

Beamish, F. W., Niimi, A. J., Lett, P. F. (1975). Bioenergetics of teleost fishes: environmental influences. In: Bolis, L., Maddrell, H. P., Schmidt-Nielsen, K. (eds.) Comp. Physiol. functional aspects of structural materials. North Holland Publishing Co., Amsterdam, p. 187-209

Beauvalet, H. (1933). Physiologie de l'hepatopancreas cez quelques telosteens. C. $r$. Séanc. Soc. Biol. 113: 242-244

Birch, W. R. (1975). Some chemical and calorific properties of tropical marine angiosperms compared with those of other plants. J. appl. Ecol. 12: 201-212

Bowen, S. H. (1976). Mechanisms for digestion of detrital bacteria by the cichlid fish. Sarother don mossambicus. Nature, Lond. 260: 137-138

Buckley, L. J., Dillmann, D. W. (1982). Nitrogen utilization by larval summer flounder, Paralichthys dertatus. J. exp. mar. Biol. Ecol. 59: 243-256

Burkholder, P. R., Burkholder, L. M., Rivero, J. A. (1959). Some chemical constituents of turtle grass, Thallassia testudinum. Bull. Torrey bot. Club 86: 88-93

Chao, L. N. (1973). Digestive systems and feeding habits of the cunner, Tautogolabrus adspersus, a stomachless fish. Fish. Bull. U.S. 71: (2) 565-586

Chesley, L. C. (1934). The concentration of protease, amylase and lipase in curtain marine fishes. Biol. Bull. mar. biol. Lab., Woods Hole 66: 133-144
Collette, B. B. (1974). The garfishes (Hemiramphidae) of Australia and New Zealand. Rec. Aust. Mus. 29 (2): 11-105

Conacher, M. J., Lanzing, W. J., Larkum, A. W. (1979). Ecology of Botany Bay II aspects of the feeding ecology of the fanbellied leatherjacket Monacanthus chinensis in Posidonia australis seagrass beds in Quibray Bay, Botany Bay, N.S.W. Aust. J. mar. Freshwat. Res. 30: 387-400

Conover, R. J. (1978). Transformation of organic matter. In: Kinne, O. (ed.) Marine ecology, Vol. IV, Dynamics. Wiley, Chichester, p. 221-456

Crampton, E. W., Harris, L. E. (1969). Applied animal nutrition (2nd ed.). Freeman, San Francisco

Elliot, J. M. (1972). Rates of gastric evacuation in brown trout. Salmo trutta. Freshwat. Biol. 2: 1-18

Elliot, J. M. (1978). The estimation of daily rates of food consumption for fish. J. Anim. Ecol. 47: 977-991

Fenchel, T. (1972). Aspects of decomposer food chains in marine benthos. Verh. dt. Zool. Ges. 65. Jahresversamml. 14: $14-22$

Fish, G. R. (1960). The comparative activity of some digestive enzymes in the alimentary canal of Tilapia and Perch. Hydrobiologia 15: 161-178

Flowerdew, M. W., Grove, D. J. (1979). Some observations of the effects of body weight, temperature, meal size and quality on gastric emptying time in the turbot, Scophthalmus maxima using radiography. J. Fish. Biol. 14 (3): $229-238$

Gohar, H. A., Latif, A. F. (1961). The carbohydrates of some scarid and labrid fishes (from the Red Sea). Publs mar. biol. Stn Ghardaqa 11: 127-146

Grodzinski, W., Kiekowski, R. Z., Duncan, A. (1975). Methods for ecological bioenergetics. IBP Handbook No. 24. Blackwell, Oxford

Grove, D. J., Loizides, L. G., Nott, J. (1978). Satiation amount, frequency of feeding and gastric emptying rate in Salmo gairdneri. J. Fish. Biol. 12: 507-516

Harrison, P. G., Mann, K. H. (1975), Chemical changes during the seasonal cycle of growth and decay in eelgrass (Zostera marina) on the Atlantic coast of Canada. J. Fish. Res. Bd Can. 32: 615-621

Hickling, C. F. (1966). On the feeding process in the white amur Ctenopharynqodon idelba. J. Zool., Lond. 148: $408-419$

Ishida, J. (1936). Distribution of the digestive enzymes in the digestive system of stomachless fishes. Annot. Zool. Jap. $15(3): 263-284$

Kapoor, B. G., Smit, H., Verighnia, I. A. (1975). The alimentary canal and digestion in Teleosts. Adv. mar. Biol. 13: $109-239$

Karlson, P. (1968). Introduction to modern biochemistry (3rd ed.). Academic Press, New York and London

Lee, D. J., Putnam, G. B. (1973). The response of rainbow trout to varying protein/energy ratios in a test diet. J. Nutr. 103: 916-922

Ling, J. K. (1958). The sea garfish, Rephorhamphus melanochir (Cuvier \& Valenciennes) (Hemiramphidae), in South Australia: breeding, age determination and growth rate. Aust. J. mar. Freshwat. Res. 9 (1): 60-110

Lobel, P. S. (1981). Trophic biology of herbivorous reef fishes: alimentary $\mathrm{pH}$ and digestive capabilities. J. Fish. Biol. 19: 365-397

Lobel, P. S., Ogden, J. C. (1981). Foraging by the herbivorous parrotfish (Sparisoma radians). Mar. Biol. 64: 173-183

McRoy, C. P. (1970). Standing stocks and other factors of Eelgrass (Zostera marina) populations on the coast of Alaska. J. Fish. Res. Bd Can. 27: 1811-1821 
Mann, K. H. (1965). Energy transformations by a population of fish in the River Thames. J. Anim. Ecol. 34: 253-275

Mann, K. H. (1969). The dynamics of aquatic ecosystems. Adv. ecol. Res. 6: 1-71

Mann, K. H. (1972). Macrophyte production and detritus food chains in coastal waters. Memorie Ist. ital. Idrobiol. 29 (Suppl.): 353-383

Mathavan, S., Vivekanandan, E., Pandian, T. J. (1976). Food utilization in the fish Tilapia mossambica fed on plant and animal foods. Helgoländer wiss. Meeresunters. 28: 66-70

Mayzaud, P., Martin, J. H. (1975). Some aspects of the biochemical and mineral composition of marine plankton. J. exp. mar. Biol. Ecol. 17: 297-310

Moriarty, D. J. W. (1973). The physiology of digestion of bluegreen algae in the cichlid fish Tilapia nilcotica. J. Zool., Lond. 171: 25-39

Murray, R. M., Marsh, H., Heinsohn, G. E., Spain, A. V. (1977). The role of the midgut caecum and large intestine in the digestion of seagrasses by the dugong (Mammalia: Sirena). Comp. Biochem. Physiol. 56a: 7-10

Nichols, P. D., Klumpp, D. W., Johns, R. B. (1982). Study of food chains in seagrass communities. Part I. Lipid components of the seagrasses Posidonia australis and Heterozostera tasmanica as indicators of carbon source. Phytochemistry 21 (7): 1613-1621

Nicotri, M. E. (1980). Factors involved in herbivore food preference. J. exp. mar. Biol. Ecol. 42: 13-26

Ogden, J. C. (1976). Some aspects of herbivore plant relationships on Caribbean reefs and sea-grass beds. Aquat. Bot. 2: $103-116$

Ogden, J. C., Lobel, P. S. (1978). The role of herbivorous fishes and urchins in coral reef communities. Environ. Biol. Fish. 3: $49-63$

Ott, J. A., Maurer, L. (1977). Strategies of energy transfer from marine macrophytes to consumer level: the Posidonia oceanica example. In: Keegan, B. F. (ed.) Biology of benthic organisms. Pergamon Press, Oxford and New York, p. 493-502

Pandian, T. J. (1967). Intake, digestion, absorption and conversion of food in the fishes Megalops cyprinoides and Opiocephalus striatus. Mar. Biol. 1: 16-32

Payne, A. I. (1978). Gut $\mathrm{pH}$ and digestive strategies in estuarine grey mullet (Mugilidae) and Tilapia. J. Fish Biol. 13: 627-629

Phillips, R. C., McRoy C. P. (eds.) (1980). Handbook of seagrass biology: an ecosystem perspective. Garland STPM Press, New York

Randall, J. E. (1967). Food habits of reef fishes of the West Indies. Stud. Trop. Oceanogr. 5: 665-847

Robertson, A. 1., Howard, R. K. (1978). Diel trophic relationships between vertically-migrating zooplankton and their fish predators in an eelgrass community. Mar. Biol. 48 207-213

Robertson, A. I., Klumpp, D. W. (1983). Feeding habits of the southern Australian garfish, Hyporhamphus melanochir a diumal herbivore and noctumal carnivore. Mar. Ecol. Prog. Ser. 10: 197-206

Rosenthal, H., Paffenhofer, G. A. (1972). On the digestion rate and calorific content of food and faeces in young garfish. Naturwissenschaften 59: 274-275

Rozin, P., Mayer, J. (1964). Some factors influencing shortterm food intake in goldfish. Am. J. Physiol. 206: $1430-1436$

Russell-Hunter, W. D. (1970). Aquatic productivity: an introduction to some basic aspects of biological oceanography and limnology. Collier-Macmillan, London

Smith, R. L., Paulson, A. C. (1974). Food transit times and gut $\mathrm{pH}$ in two Pacific parrot fishes. Copeia 1974 (3): 796-799

Suyehiro, Y. (1942). A study of the digestive system and feeding habits of fish. Jap. J. Zool., Lond. 10: 1-300

Talwar, P. K. (1962). Studies on the food and feeding relationship of the halfbeak fishes (Hemirhamphidae) from the Gulf of Mannar and Palk Bay. Indian J. Fish. 9 (1a): 1-9

Thompson, J. M. (1957). The food of West Australian estuarine fish. Fish. Bull. West. Aust. 7: 1-13

Thompson, J. M. (1959). Some aspects of the ecology of Lake Macquarie N.S.W. with regard to an alleged depletion of fish. LX. The fishes and their food. Aust. J. mar. Freshwat. Res. 10: 365-374

Thorpe, J. E. (1977). Daily ration of adult perch, Perca fuviatilus during summer in Loch Leven, Scotland. J. Fish. Biol. 11: 55-68

Tseitlin, V. B. (1980). Duration of gastric digestion in fishes. Mar. Ecol. Prog. Ser. 2: 277-280

Tyler, A. V. (1970). Rate of gastric emptying in young cod. J. Fish Res. Bd Can. 27: 1177-1189

Van Dyke, J. M., Sutton, D. L. (1977). Digestion of duckweed (Lemna spp.) by the grass carp (Ctenopharyngodon idella). J. Fish Biol. 11: 273-278

Van Soest, P. J. (1963). Use of detergents in the analysis of fibrous feeds II A rapid method for determination of fibre and lignin. J. Ass. off. agric. Chem. 46: 829-836

Van Soest, P. J., Wine, R. H. (1967). Use of detergents in the analysis of fibrous feeds. IV Determination of plant cellwall constituents. J. Ass, off. agric. Chem. 50: 53-64

Vinogradov, A. P. (1953). The elementary chemical composition of marine organisms. Memoir 2, Par, A. E., Olsen, Y. N. (eds.) Sears Foundation for Marine Science, Yale, New Haven

Winberg, G. G. (1956). Rate of metabolism and food requirements of fishes, J. Fish. Res. Bd Can. (Transl. Ser.) 194 